\title{
Effect of 8 weeks of pre-season training on body composition, physical fitness, anaerobic capacity, and isokinetic muscle strength in male and female collegiate taekwondo athletes
}

\author{
Myong-Won Seo, Hyun-Chul Jung, Jong-Kook Song, Hyun-Bae Kim* \\ Department of Physical Education, College of Physical Education, Kyung Hee University, Yongin, Korea
}

The purpose of the study was to determine the effect of 8 weeks pre-season training on body composition, physical fitness, anaerobic capacity, and isokinetic strength in collegiate taekwondo athletes. Thirty-four collegiate athletes (male: 22, female: 12) participated. Body composition, bone mineral density, physical fitness, anaerobic capacity, and isokinetic muscle strength were tested. After statistical analysis was performed the results indicated that there were significant decreases in body weight, percent body fat, and fat tissue after 8 weeks of pre-season training. Bone mineral density increased significantly only in males. There were significant improvements in the $50 \mathrm{~m}$ shuttle run and $20 \mathrm{~m}$ multistage endurance run in both males and females. The sit $\&$ reach test and standing long jump were not significantly changed after 8 weeks. Relative peak power and anaerobic capacity were signifi- cantly improved in males. Significant increases in angular velocity were observed for knee extension at both $\% \mathrm{BW} 60 \% \mathrm{sec}$ and $180 \% \mathrm{sec}$ in both males and females. A significant increase in angular velocity was seen for right knee flexion at $\% \mathrm{BW} 60 \% \mathrm{sec}$ for males, but it decreased at $\%$ BW $180 \%$ sec for both males and females. In conclusion, this study suggests that 8 weeks of pre-season training has a positive effect on body composition, physical fitness, anaerobic capacity, isokinetic muscular strength, and endurance. Nevertheless, an exercise approach with the goal of increasing lean tissue, and improving power in knee flexors and flexibility of athletes, should be included in the training program.

Keywords: Body composition, Physical fitness, Anaerobic capacity, Isokinetic muscle strength, Taekwondo

\section{INTRODUCTION}

The objective of training for athletes is to improve factors such as body composition correct for their sport, physical fitness, technical, and psychological skills, and to optimize athletic performance (Bridge et al., 2014; Buchheit et al., 2013). Pre-season training improves the physical performance of athlete's depleted performance. Fitness evaluation can predict performance during the season and contribute to attainment of program goals (Argus et al. 2010).

Among factors that evaluate the performance of elite athletes, fat tissue and lean tissue are important indicators that verify the effect of training, in light of differences in type of sport, gender, and performance levels, and reportedly influence the early selection of elite athletes and their performance (Desiere et al., 2004; Mudd et al., 2007). In the case of taekwondo, in particular, it is reported that elite athletes have higher lean mass and lower fat mass than non-elite athletes (Bridge et al., 2014; Fritzsche and Raschka, 2007; Markovic et al., 2005). In relation to physical fitness, factors such as agility, strength, endurance and flexibility are considered very important in taekwondo competition (Bridge et al., 2014; Casolino et al., 2012; Markovic et al., 2005). Since more than $90 \%$ of scoring is based on kicking skills, in particular, muscle power and endurance in the lower extremities are required (Casolino et al., 2012; Matsushigue et al., 2009; Santos et al., 2011; Tornello et al., 2013). In addition, during a two-minute,
${ }^{*}$ Corresponding author: Hyun-Bae Kim

Department of Physical Education, College of Physical Education, Kyung Hee University, 1732 Deokyoungdae-ro, Giheung-gu, Yongin 446-701, Korea Tel: +82-31-201-2716, Fax: +82-31-204-8117, E-mail: hbkim5@khu.ac.kr Received: March 30, 2015 / Accepted: April 8, 2015
This is an Open Access article distributed under the terms of the Creative Commons Attribution Non-Commercial License (http://creativecommons.org/licenses/by-nc/3.0/) which permits unrestricted non-commercial use, distribution, and reproduction in any medium, provided the original work is properly cited. 
three-round taekwondo match, mean heart rates (Mean HR) of athletes can reach $85 \%$ of maximum (HR max), validating it as a high-intensity sport (Bridge et al., 2013; Chiodo et al., 2011; Matsushigue et al., 2009); thus, performance relies heavily on anaerobic metabolism, since scoring is achieved through attacks within very brief time intervals, e.g. 3-5 sec (Fong et al., 2011; Marcovic et al., 2008). Therefore, athletes must be trained to improve their anaerobic capacity. As noted above, factors such as body composition, physical fitness, anaerobic capacity, and isokinetic muscle strength affect an athlete's performance in taekwondo.

Approximately 20-60\% of athletes in sports have experienced overtraining (Purvis et al., 2010), which may lead to injuries to the nerves, and the musculoskeletal and cardiovascular systems (Cosca and Navazio, 2007; Margonis et al., 2007), as well as a decline in performance. Pre-season training of taekwondo athletes, in particular, is mostly based on the experience of the coaching staff or the athletes themselves, but there is no study closely examining the factors that affect performance in competition in Korea.

This study carefully analyzed the effect of 8 weeks of pre-season training on changes in body composition, physical fitness, anaerobic capacity, and isokinetic muscle strength, with the purpose of presenting study material that can maximize the efficiency of sports training programs.

Table 1. Characteristics of the groups (Mean \pm SD)

\begin{tabular}{lcccc}
\hline & Age $(\mathrm{yr})$ & Height $(\mathrm{cm})$ & Carrier $(\mathrm{yr})$ & $(\mathrm{n})$ \\
\hline Male & $19.4 \pm 0.95$ & $176.7 \pm 7.06$ & $9.5 \pm 1.91$ & 22 \\
Female & $18.9 \pm 1.24$ & $167.9 \pm 4.28$ & $8.9 \pm 2.23$ & 12 \\
\hline
\end{tabular}

\section{MATERIALS AND METHODS}

\section{Subjects}

The randomly selected subjects were 34 male and female athletes 18-21 yr old, who attended K University in Y City. None of the subjects had physical or weight loss problems, or were taking any medication. They were informed of the test procedures before providing written consent. The characteristics of the research subjects are shown in Table 1.

\section{Variables}

\section{Body composition}

The effects of the taekwondo training program on body composition were determined. Estimates of percent body fat were calculated based on measurements of fat and lean tissue and bone mineral density via dual X-ray absorptiometry (DXA, Hologic QDR4500 , USA). The coefficient of variance of scanning was $1.5 \%$, which is in agreement with that indicated by the manufacturer.

\section{Physical fitness}

The Eurofit physical fitness test (1988) was used, and 9 variables for 4 factors were tested. Each test was performed according to the following sequence: flexibility (sit and reach), power (standing long jump), agility (50 m shuttle run), and cardiorespiratory endurance (20 m multistage endurance run).

\section{Wingate anaerobic power test}

The Wingate anaerobic power test (WAPT) was performed on a cycle ergometer (Monark 707, Sweden). Before beginning the test

Table 2. Training program

\begin{tabular}{|c|c|c|c|}
\hline & Program & Load & Time \\
\hline \multirow[t]{4}{*}{ Morning } & Warm-up & & $20 \mathrm{~min}$ \\
\hline & 1) High-intensive continuous running & $85-95 \%>$ HRmax & $40 \min$ \\
\hline & 2) Plyometric & $85-95 \%>$ HRmax & $40 \mathrm{~min}$ \\
\hline & Cool down & & $20 \mathrm{~min}$ \\
\hline \multirow[t]{4}{*}{ Afternoon } & Warm-up & & $20 \mathrm{~min}$ \\
\hline & 3) Long, Slow distance & $60-80 \%>$ HRmax & $30 \mathrm{~min}$ \\
\hline & 4) Circuit training & 20REP/3set & $50 \mathrm{~min}$ \\
\hline & Cool down & & $20 \mathrm{~min}$ \\
\hline \multirow[t]{3}{*}{ Evening } & Warm-up & & $20 \mathrm{~min}$ \\
\hline & 5) Sit-up \& Push up training & 40REP/3set & $50 \mathrm{~min}$ \\
\hline & Cool down & & $20 \mathrm{~min}$ \\
\hline
\end{tabular}

Circuit training: (1) Chest-press, (2) Biceps-curl, (3) Triceps extension, (4) Seated dip, (5) Shoulder press, (6) Real delt, (7) Switch foot box drill with barbell, (8) Squat barbell-jump, (9) Jerk, (10) Power clean, (11) Leg press, (12) Leg extension. Sit-up \& Push-up program: (1) V-up, (2) Push-up, (3) Scissors kick, (4) Diamond Push-up, (5) Back extension, (6) Wide hands Push-up, (7) V-up combination. 
the seat was adjusted to the participant's height. This was followed by a 2-3-min warm-up. The 30-sec test used a load of $0.075 \mathrm{kp}$ per $\mathrm{kg}$ the subject's body weight. The number of revolutions pedaled during every 5-sec interval was recorded. Variables measured included relative peak power, anaerobic capacity, and fatigue index.

\section{Isokinetic strength}

Isokinetic dynamometry (Cybex, 770 NORM, USA) was performed to evaluate flexion and extension of the right and left knees. Each test included 3 maximal contractions at $60 \%$ sec for muscle strength, and 20 maximal contractions at $180 \%$ sec for muscle endurance. Each isokinetic contraction was performed through a full range of motion, and data were normalized to each participant's body weight, and calculated as torque and total work done $([\mathrm{Nm}] \div[\mathrm{kg}]) \times 100$.

\section{Training program and training Intensity}

As shown in Table 2, the training program included high-intensity continuous running and stair climbing in the morning, low-intensity continuous running and circuit training in the afternoon, and a program of sit-ups and push-ups in the evening. High-intensity continuous running was conducted at $85-90 \%$ of HRmax, and long, slow distance running at $60-80 \%$ of HRmax. Circuit training and was conducted at $40-60 \%$ intensity, of 20 repetitions each section. The sit-up and push-up program consisted of 3 sets of 40 repetitions. To monitor the work intensity during each training session, a heart rate monitor (Polar, RS 400, USA) was used. The average heart rate for each session was divided by 100 to calculate an index of mean exercise intensity.

\section{Statistical analysis}

Statistical analysis was performed using the SAS version 9.2 (SAS Institute, NC, USA) software for Windows. All data were presented as mean and standard deviation values. A paired t-test was used to analyze changes over time for each parameter. A $P<0.05$ was considered as statistically significant.

\section{RESULTS}

\section{Body composition}

Changes in body composition of collegiate taekwondo athletes after 8 weeks of pre-season training are presented in Table 3. As a result of training, there was a statistically significant reduction in weight $(P<0.05, P<0.01$, respectively) for both males and females. Percent body fat of males decreased from $11.4 \pm 2.28 \%$ before to $9.9 \pm 1.50 \%$ after training $(P<0.0001)$, and fat tissue reduced from $8.1 \pm 2.30 \mathrm{~kg}$ to $6.8 \pm 1.52 \mathrm{~kg}(P<0.0001)$. Percent body fat of females reduced from $23.2 \pm 3.58 \%$ before to $21.2 \pm 3.09 \%$ after training $(P<0.001)$, and fat tissue also significantly reduced from $14.0 \pm 3.0 \mathrm{~kg}$ to $12.4 \pm 2.48 \mathrm{~kg}(P<0.001)$. There was no statistically significant difference in lean tissue for either males or females. Bone mineral content increased significantly in males, from 3,031.1 $\pm 404.41 \mathrm{~g}$ before to $3,049.8 \pm 403.53 \mathrm{~g}$ after training $(P<0.001)$, and bone density increased from $1.29 \pm 0.09 \mathrm{~g} / \mathrm{cm}^{2}$ before to $1.31 \pm 0.10 \mathrm{~g} / \mathrm{cm}^{2}$ after training $(P<0.05)$.

\section{Physical fitness}

Changes in physical fitness are presented in Table 4 . The effect of training on flexibility (sit and reach) and power (standing long jump) was not significant for either males or females. Agility ( $50 \mathrm{~m}$

Table 3. Change of body composition during 8 weeks of pre-season training in collegiate taekwondo athletes

\begin{tabular}{|c|c|c|c|c|c|}
\hline & Group & Pre & Post & $\Delta \%$ & $\mathrm{t}$-value \\
\hline Body mass (kg) & $\begin{array}{c}M \\
F\end{array}$ & $\begin{array}{l}69.8 \pm 9.46 \\
59.8 \pm 6.56\end{array}$ & $\begin{array}{l}68.6 \pm 8.40^{*} \\
57.9 \pm 6.41^{* *}\end{array}$ & $\begin{array}{l}-1.7 \\
-3.2\end{array}$ & $\begin{array}{l}2.42 \\
3.91\end{array}$ \\
\hline Percent fat (\%) & $\begin{array}{c}M \\
F\end{array}$ & $\begin{array}{l}11.4 \pm 2.38 \\
23.2 \pm 3.58\end{array}$ & $\begin{array}{c}9.9 \pm 1.50^{* * * * * *} \\
21.2 \pm 3.09^{* * * *}\end{array}$ & $\begin{array}{r}-13.2 \\
-8.6\end{array}$ & $\begin{array}{l}5.44 \\
4.06\end{array}$ \\
\hline Fat tissue $(\mathrm{kg})$ & $\begin{array}{c}M \\
F\end{array}$ & $\begin{array}{r}8.1 \pm 2.30 \\
14.0 \pm 3.00\end{array}$ & $\begin{array}{r}6.8 \pm 1.52^{* * * *} \\
12.4 \pm 2.48^{* * *}\end{array}$ & $\begin{array}{l}-16.0 \\
-11.4\end{array}$ & $\begin{array}{l}4.48 \\
4.93\end{array}$ \\
\hline Lean tissue (g) & $\begin{array}{c}M \\
F\end{array}$ & $\begin{array}{l}58.9 \pm 7.69 \\
43.6 \pm 4.71\end{array}$ & $\begin{array}{l}58.7 \pm 6.96 \\
43.2 \pm 5.16\end{array}$ & $\begin{array}{r}0.0 \\
-1.0\end{array}$ & $\begin{array}{l}0.58 \\
0.95\end{array}$ \\
\hline $\mathrm{BMC}(\mathrm{g})$ & $\begin{array}{c}M \\
F\end{array}$ & $\begin{array}{l}3,031.1 \pm 401.41 \\
2,461.9 \pm 333.91\end{array}$ & $\begin{array}{l}3,049.8 \pm 403.53^{* *} \\
2,462.7 \pm 331.43\end{array}$ & $\begin{array}{l}1.0 \\
0.0\end{array}$ & $\begin{array}{l}-2.74 \\
-0.06\end{array}$ \\
\hline $\mathrm{BMD}\left(\mathrm{g} / \mathrm{cm}^{2}\right)$ & $\begin{array}{c}M \\
F\end{array}$ & $\begin{array}{r}1.29 \pm 0.09 \\
1.206 \pm 0.09\end{array}$ & $\begin{array}{r}1.31 \pm 0.10^{*} \\
1.211 \pm 0.09\end{array}$ & $\begin{array}{l}1.6 \\
0.0\end{array}$ & $\begin{array}{l}-2.42 \\
-0.83\end{array}$ \\
\hline
\end{tabular}

Values are mean \pm SD. Significantly different between pre-test and post-test. ${ }^{~} P<0.05 .{ }^{* * *} P<0.01$. ${ }^{* * *} P<0.001$. ${ }^{* * * *} P<0.0001$. 
shuttle run) significantly positive effect for males, from 17.0 \pm 0.92 sec before to $16.2 \pm 0.99 \mathrm{sec}$ after training $(P<0.0001)$; there was also an improvement for females, from $19.1 \pm 0.92 \mathrm{sec}$ before to $18.4 \pm 0.70 \mathrm{sec}$ after training $(P<0.01)$. The $20 \mathrm{~m}$ multi-stage endurance run improved significantly for males, from $107.7 \pm 9.56$ times before to $117.9 \pm 8.91$ stages after training $(P<0.0001)$; there was also a positive training effect for females, from $77.6 \pm 11.21$ times to $87.4 \pm 11.37$ times $(P<0.0001)$.

\section{Wingate anaerobic power test}

Changes in anaerobic capacity of collegiate taekwondo athletes after 8 weeks of pre-season training are presented in Table 5 . Relative peak power per body weight for males significantly improved from $10.2 \pm 1.31 \mathrm{~W} / \mathrm{kg}$ before to $10.9 \pm 0.88 \mathrm{~W} / \mathrm{kg}$ after training $(P<0.05)$. Mean power for males also improved significantly from $7.5 \pm 0.67 \mathrm{~W} / \mathrm{kg}$ before to $8.3 \pm 0.59 \mathrm{~W} / \mathrm{kg}$ after training $(P<0.0001)$.

\section{Isokinetic strength}

\section{Maximum muscular strength}

Changes in isokinetic maximum muscular strength of male and female collegiate taekwondo athletes after 8 weeks of a pre-season training program are presented in Table 6. Left extensor angular velocity at $60^{\circ}$ sec significantly increased for males, from $271.9 \pm 37.12 \%$ body weight (BW) before to $315.1 \pm 39.09 \% \mathrm{BW}$ after training $(P<0.0001)$; there was also a significant increase for females, from $222.9 \pm 16.97 \%$ BW to $281.3 \pm 30.79 \%$ BW $(P<0.0001)$. Right extensor angular velocity at $60^{\circ} / \mathrm{sec}$ significantly increased for males,

Table 4. Change of physical fitness during 8 weeks of pre-season training in collegiate taekwondo athletes

\begin{tabular}{|c|c|c|c|c|c|}
\hline Variables & Group & Pre & Post & $\Delta \%$ & t-value \\
\hline Sit \& reach $(\mathrm{cm})$ & $\begin{array}{c}M \\
F\end{array}$ & $\begin{array}{l}19.8 \pm 5.72 \\
22.6 \pm 6.42\end{array}$ & $\begin{array}{l}19.8 \pm 5.59 \\
23.2 \pm 4.80\end{array}$ & $\begin{array}{l}0 \\
2.7\end{array}$ & $\begin{array}{l}-0.03 \\
-1.03\end{array}$ \\
\hline Standing long jump (cm) & $\begin{array}{c}M \\
F\end{array}$ & $\begin{array}{l}240.4 \pm 18.32 \\
192.6 \pm 14.83\end{array}$ & $\begin{array}{l}240.8 \pm 18.09 \\
196.8 \pm 9.27\end{array}$ & $\begin{array}{l}0.2 \\
2.2\end{array}$ & $\begin{array}{l}-0.25 \\
-1.76\end{array}$ \\
\hline 50 m shuttle run (sec) & $\begin{array}{c}M \\
F\end{array}$ & $\begin{array}{l}17.0 \pm 0.92 \\
19.1 \pm 0.92\end{array}$ & $\begin{array}{l}16.2 \pm 0.99^{* * * * *} \\
18.4 \pm 0.70^{* * *}\end{array}$ & $\begin{array}{l}-4.7 \\
-3.7\end{array}$ & $\begin{array}{l}5.55 \\
2.97\end{array}$ \\
\hline 20 m multistage endurance run ( $n$ ) & $\begin{array}{c}M \\
F\end{array}$ & $\begin{array}{c}107.7 \pm 9.56 \\
77.6 \pm 11.21\end{array}$ & $\begin{array}{r}117.9 \pm 8.91^{*} \\
87.4 \pm \\
11.37^{* * * * *}\end{array}$ & $\begin{array}{r}9.5 \\
12.6\end{array}$ & $\begin{array}{l}-7.02 \\
-7.18\end{array}$ \\
\hline
\end{tabular}

Values are mean $\pm S D$. Significantly different between pre-test and post-test; ${ }^{* *} P<0.05 .{ }^{* *} P<0.01 .{ }^{* * *} P<0.001 .{ }^{* * * * *} P<0.0001$.

Table 5. Change of anaerobic capacity during 8 weeks of pre-season training in collegiate taekwondo athletes

\begin{tabular}{lccccc}
\hline & Group & Pre & Post & $\Delta \%$ & $\mathrm{t}$-value \\
\hline Relative peak power $(\mathrm{w} / \mathrm{kg})$ & $\mathrm{M}$ & $10.2 \pm 1.31$ & $10.9 \pm 0.88^{*}$ & 6.9 & -2.59 \\
& $\mathrm{~F}$ & $8.7 \pm 0.61$ & $9.1 \pm 0.76$ & 4.6 & -1.57 \\
Mean power $(\mathrm{w} / \mathrm{kg})$ & $\mathrm{M}$ & $7.5 \pm 0.67$ & $8.3 \pm 0.59^{* * * *}$ & 10.7 & -5.32 \\
& $\mathrm{~F}$ & $6.2 \pm 0.59$ & $6.5 \pm 0.56$ & 4.8 & -0.36 \\
Fatigue index $(\%)$ & $\mathrm{M}$ & $44.6 \pm 8.39$ & $43.6 \pm 6.84$ & -2.2 & 0.47 \\
& $\mathrm{~F}$ & $47.3 \pm 7.55$ & $46.6 \pm 6.18$ & -1.5 & 0.39 \\
\hline
\end{tabular}

Values are mean \pm SD. Significantly different between pre-test and post-test. ${ }^{*} P<0.05 .{ }^{* * *} P<0.01 .{ }^{* * *} P<0.001 .{ }^{* * * * *} P<0.0001$.

Table 6. Change of bilateral isokinetic muscular strength at \%BW 60\% $/ \mathrm{sec}$ during 8 weeks of pre-season training in collegiate taekwondo athletes

\begin{tabular}{|c|c|c|c|c|c|}
\hline & Group & Pre & Post & $\Delta \%$ & t-value \\
\hline Left extensor peak torque \% BW (N.m/kg) & $\begin{array}{c}M \\
F\end{array}$ & $\begin{array}{l}271.9 \pm 37.12 \\
222.9 \pm 16.97\end{array}$ & $\begin{array}{l}315.1 \pm 39.09^{* * * * *} \\
281.3 \pm 30.79^{* * * * *}\end{array}$ & $\begin{array}{l}15.9 \\
26.2\end{array}$ & $\begin{array}{l}-5.77 \\
-9.15\end{array}$ \\
\hline Right extensor peak torque \% BW (N.m/kg) & $\begin{array}{c}M \\
F\end{array}$ & $\begin{array}{l}274.3 \pm 39.83 \\
223.7 \pm 14.29\end{array}$ & $\begin{array}{l}327.5 \pm 40.14^{* * * *} \\
278.5 \pm 30.69^{* * *}\end{array}$ & $\begin{array}{l}19.4 \\
24.5\end{array}$ & $\begin{array}{l}-6.4 \\
-7.35\end{array}$ \\
\hline Left flexor peak torque \% BW (N.m/kg) & $\begin{array}{c}M \\
F\end{array}$ & $\begin{array}{l}192.9 \pm 21.22 \\
152.8 \pm 14.42\end{array}$ & $\begin{array}{l}198.4 \pm 21.61 \\
160.0 \pm 14.77\end{array}$ & $\begin{array}{l}2.9 \\
4.7\end{array}$ & $\begin{array}{l}-1.25 \\
-1.26\end{array}$ \\
\hline Right flexor peak torque \% BW (N.m/kg) & $\begin{array}{c}M \\
F\end{array}$ & $\begin{array}{l}182.5 \pm 24.32 \\
155.0 \pm 13.90\end{array}$ & $\begin{array}{l}196.0 \pm 21.35^{*} \\
159.0 \pm 16.40\end{array}$ & $\begin{array}{l}7.4 \\
2.6\end{array}$ & $\begin{array}{l}-2.66 \\
-0.83\end{array}$ \\
\hline
\end{tabular}

Values are mean \pm SD. Significantly different between pre-test and post-test. ${ }^{*} P<0.05$. ${ }^{* * *} P<0.01$. ${ }^{* * * *} P<0.001$. ${ }^{* * * * *} P<0.0001$. 
Table 7. Change of bilateral isokinetic muscular endurance at \%BW $180 \%$ sec during 8 weeks of pre-season training in collegiate taekwondo athletes

\begin{tabular}{|c|c|c|c|c|c|}
\hline & Group & Pre & Post & $\Delta \%$ & t-value \\
\hline Left extensor total work \%BW (N.m/kg) & $\begin{array}{c}M \\
F\end{array}$ & $\begin{array}{l}3,676.0 \pm 445.28 \\
2,891.2 \pm 324.94\end{array}$ & $\begin{array}{l}4,651.4 \pm 417.39^{* \ldots * * *} \\
3,736.7 \pm 311.74^{* \ldots * *}\end{array}$ & $\begin{array}{l}26.5 \\
31.0\end{array}$ & $\begin{array}{l}-5.77 \\
-9.15\end{array}$ \\
\hline Right extensor total work \%BW (N.m/kg) & $\begin{array}{c}M \\
F\end{array}$ & $\begin{array}{l}3,660.7 \pm 521.67 \\
2,926.9 \pm 415.65\end{array}$ & $\begin{array}{l}4,696.1 \pm 416.01^{* * * * *} \\
3,576.5 \pm 365.05^{* * *}\end{array}$ & $\begin{array}{l}28.3 \\
22.2\end{array}$ & $\begin{array}{l}-6.4 \\
-7.35\end{array}$ \\
\hline Left flexor total work \%BW (N.m/kg)) & $\begin{array}{c}M \\
F\end{array}$ & $\begin{array}{l}3,473.0 \pm 420.16 \\
2,647.0 \pm 389.91\end{array}$ & $\begin{array}{l}3,209.1 \pm 431.10^{*} \\
2,287.0 \pm 475.91^{*}\end{array}$ & $\begin{array}{r}-7.6 \\
-13.6\end{array}$ & $\begin{array}{l}-1.25 \\
-1.26\end{array}$ \\
\hline Right flexor total work \%BW (N.m/kg) & $\begin{array}{c}M \\
F\end{array}$ & $\begin{array}{l}3,278.9 \pm 627.75 \\
2,504.5 \pm 381.51\end{array}$ & $\begin{array}{l}3,101.4 \pm 509.01 \\
2,291.3 \pm 405.63\end{array}$ & $\begin{array}{l}-5.4 \\
-8.5\end{array}$ & $\begin{array}{l}-2.66 \\
-0.83\end{array}$ \\
\hline
\end{tabular}

Values are mean \pm SD. Significantly different between pre-test and post-test. ${ }^{*} P<0.05 .{ }^{* *} P<0.01 .{ }^{* * * *} P<0.001 .{ }^{* * * *} P<0.0001$.

from $274.3 \pm 39.83 \%$ BW before to $327.5 \pm 40.14 \%$ BW after training $(P<0.001)$; there was also a significant increase for females, from $223.7 \pm 14.29 \%$ BW before to $278.5 \pm 30.69 \%$ BW after training $(P<0.05)$. Right flexor angular velocity at $60 \%$ sec significantly increased for males, from $182.5 \pm 24.32 \% \mathrm{BW}$ to $196.0 \pm 21.35 \% \mathrm{BW}$ $(P<0.05)$, but there was no significant change for females.

\section{Muscle endurance}

Changes in isokinetic muscle endurance of male and female collegiate taekwondo athletes after an 8-week pre-season training program are presented in Table 7. Left extensor angular velocity at $180^{\circ}$ sec significantly increased for males, from 3,676.0 $4445.28 \%$ BW before to $4,651.4 \pm 417.39 \% \mathrm{BW}$ after training $(P<0.0001)$; there was also a significant increase for females, from 2,891.2 $\pm 324.94 \%$ BW to 3,736.7 $\pm 311.74 \%$ BW $(P<0.0001)$. Right extensor angular velocity at $180 \%$ sec significantly increased for males, from 3,660.7 $\pm 521.67 \%$ BW before to 4,696.1 $\pm 416.01 \%$ BW after training $(P<0.0001)$; there was also a significant increase for females, from 2,926.9 $\pm 415.65 \% \mathrm{BW}$ to 3,576.5 $\pm 365.05 \% \mathrm{BW}(P<0.01)$. Left flexor angular velocity at $180^{\circ} / \mathrm{sec}$ significantly decreased for males, from 3,473.0 $\pm 420.16 \%$ BW before to 3,209.1 $\pm 431.1 \%$ BW after training $(P<0.05)$; there was also a significant decrease for

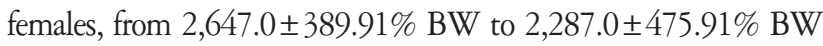
$(P<0.05)$.

\section{DISCUSSION}

\section{Body composition}

Body composition plays an important role in determining an elite athlete and is closely related to performance (Stanforth et al., 2014; Zemski et al., 2015). The level of body fat, together with anaerobic and aerobic capacity, not only influences physical fitness factors, such as agility and power, but is also related to menstrual irregularity and amenorrhea in female athletes (Casajus, 2001;
Duthie et al., 2003; Pitts et al., 2014; Sedeaud et al., 2012).

In the present study, 8 weeks of pre-season training for collegiate male and female taekwondo athletes significantly decreased percentage body fat and fat tissue. However, despite a positive pre-season training effect, with significant reduction in percent body fat, female athletes in this study still had a higher percentage than the national women's teams of Croatia $(14.8 \pm 1.7 \%)$, Germany $(15.8 \pm 2.5 \%)$ and Italy $(16.5 \pm 4.9 \%)$ (Chiodo et al., 2011; Fritzsche and Raschka, 2007). Although it is difficult to make a direct comparison, these results may be due to the difference in measuring devices or performance levels of a national as opposed to a collegiate team.

There was no significant change in lean tissue for either males or females, in contrast to the results of Ratamess et al. (2012) with pre-season training for wrestlers, and the 4 week intensive training study of Argus et al. (2010). Results in this study may reflect the 8 weeks of primarily aerobic training, limiting opportunities for lean tissue improvement. In future studies, improvements that can maximize lean tissue through the introduction of weight training programs are therefore necessary.

Generally, at least 24 weeks of weight-bearing exercise are reportedly required to increase bone mineral density. The present study showed significant increases in bone mineral content and bone density, with exceptional results compared to those in the study by Guadalupe et al. (2009). However, since the number of subjects was small, caution is recommended in generalizing the results. Further research on bone density, considering factors such as gender, training intensity and duration, and body region, is necessary.

\section{Physical fitness}

Elite taekwondo athletes maintain a higher level of physical fitness than non-elite athletes. The pre-season training in the present study significantly improved the $50 \mathrm{~m}$ shuttle run and $20 \mathrm{~m}$ mul- 
tistage endurance run results for males and females, but did not change sit and reach and standing long jump results. This may be a drawback of the current training program. Flexibility is important because differential scoring, favoring head points and lower extremity power during a competition, works adversely in a firstto-score golden point system during overtime (Kim et al., 2015). Therefore, sufficient stretching time before and after the match is necessary to improve the range of motion of joints, and readjusting the training program to improve power should be helpful.

\section{Anaerobic capacity and Isokinetic muscle strength}

An increase in lean mass requires at least 2 months of training, and an increase in muscle strength, resulting from a short period of training, is reportedly the result of neural adaptation. Although the short training time of the present study did have effects beyond maintaining lean tissue, there was improvement in relative peak power and anaerobic capacity for males, and a tendency toward an increase in females. Weber et al. (2006) reported a 10\% maximum difference in anaerobic capacity with respect to lean tissue, but this was not apparent in the present study. This contrasting finding demonstrates that relative peak power and anaerobic capacity may increase without a significant change in lean body mass; however, the results would have been better had there been an increase in lean tissue (Argus et al. 2010).

The measurement of extensor and flexor strength in taekwondo athletes is an important indicator for monitoring training effects, and is a widely used objective evaluation method with good reproducibility (Coburn et al., 2006; Kim et al., 2011). Scoring, in 2-min, 3-round taekwondo matches requires muscle strength in the lower extremities; with at least 4-6 matches in a day, muscle endurance is also very important.

Isokinetic training results of knee joints before and after the pre-season training in the present study show that, except for left and right flexor angular velocity at $\% \mathrm{BW} 60 \%$ sec, left and right extensor angular velocity at $\% \mathrm{BW} 60 \%$ sec increased significantly for both males and females, representing improvements in extensor strength. There was also a significant increase in left and right extensor angular velocity at \% BW $180 \%$ sec for both males and females, thus showing improvements in extensor endurance; however, left flexor angular velocity at \% BW $180^{\circ} /$ sec significantly decreased, thus showing a decline in flexor endurance. A significant decrease in left flexor angular velocity at \% BW $180^{\circ}$ sec, and a tendency toward decreasing flexor strength at an angular velocity of $\% \mathrm{BW} 60^{\circ} \mathrm{sec}$, can be explained by the composition of the training program in the present study; training was good for the development of the quadriceps, through running and jumping, but not effective for the development of the hamstring, in which flexor muscles play a relatively important role.

In taekwondo, kicking velocity of the leg is as important as folding velocity; one must fold the leg after making a kick, using the flexor as quickly as possible, to make the following kick quickly and accurately. Therefore, supplemental activities that can strengthen the flexor muscles, such as weight training with leg curls, or resistance training using elastic bands, is necessary, and annual program modifications during pre-season training evaluations should be conducted.

In addition, although there was no increase in lean tissue, increases in left and right extensor angular velocities at $\% \mathrm{BW} 60 \%$ sec and $\%$ BW $180 \%$ sec were possibly driven by neural adaptation, resulting from the combined action of muscle and a neural factor. In this regard, further detailed studies are necessary (Barnes, 1980).

\section{CONFLICT OF INTEREST}

No potential conflict of interest relevant to this article was reported.

\section{REFERENCES}

Argus CK, Gill N, Keogh J, Hopkins WG, Beaven CM. Effects of a shortterm pre-season training programme on the body composition and anaerobic performance of professional rugby union players. J Sports Sci 2010;28(6):679-686.

Barnes WS. The relationship of motor unit activation to isokinetic muscular contraction at difference contractile velocities. Phys Ther 1980; 60(9): 1152-1158.

Bridge CA, Ferreira SSJ, Chaabene H, Pieter W, Franchini E. Physical and physiological profiles of taekwondo athletes. Sports Med 2014; 44(6): 713-733.

Bridge CA, McNaughton LR, Close GL, Drust B. Taekwondo exercise protocols do not recreate the physiological responses of championship combat. Int J Sports Med 2013;34:573-581.

Buchheit M, Racinais S, Bilsborough JC, Bourdon PC, Voss SC, Hocking J, Cordy J, Mendez-Villanueva A, Coutts AJ. Monitoring fitness, fatigue and running performance during a pre-season training camp in elite football players. J Sci Med Sport 2013;16(6):550-555.

Casajus JA. Seasonal variation in fitness variables in professional soccer player. J Sports Med Phys Fitness 2001;41(4):463-469.

Casolino E, Cortis C, Lupo C, Chiodo S, Minganti C, Capranica L. Physio- 
logical versus psychological evaluation in taekwondo elite athletes. Int J Sports Physiol Perform 2012;7:322-331.

Chiodo S, Tessitore A, Cortis C, Lupo C, Ammendolia A, Iona T, Capranica L. Effects of official Taekwondo competitions on all-out performances of elite athletes. J Strength Cond Res 2011;25:334-339.

Coburn JW, Housh TJ, Malek MH, Weir JP, Cramer JT, Beck TW, Johnson GO. Neuromuscular responses to three days of velocity specific isokinetic training. J Strength Cond Res 2006;20(4):892-898.

Cosca, DD, Navazio F. Common problems in endurance athletes. Am Fam Physician 2007;76(2):237-244.

Desiere F. Towards a systems biology understanding of human health: interplay between genotype, environment and nutrition. Biotechnol Annu Rev 2004;10:51-84.

Duthie G, Pyne D, Hooper S. Applied physiology and game analysis of rugby union. Sports Med 2003;33:973-991.

Fong SS, Ng GY. Does Taekwondo training improve physical performance? Phys Ther Sport 2011;12(2):100-106.

Fritzsche J, Raschka C. Sports anthropological investigations on somatotypology of elite karateka. Anthropol Anz 2007;65(3):317-329.

Guadalupe GA, Fuentes T, Guerra B, Calbet JA. Exercise and Bone Mass in Adults. Sports Med 2009;39(6):439-468.

Kim HB, Jung HC, Song JK, Chai JH, Lee EJ. A follow-up study on the physique, body composition, physical performance, and isokinetic strength of female collegiate Taekwondo athletes. J Exerc Rehabil 2015;11(1):57-64.

Kim HB, Stebbins CL, Chai JH, Song JK. Taekwondo training and fitness in female adolescents. J Sports Sci 2011;29(2):133-138.

Margonis K, Fatouros IG, Jamurtas AZ, Nikolaidis MG, Douroudos I, Chatzinikolaou A, Mitrakou A, Mastorakos G, Papassotiriou I, Taxildaris K, Kouretas D. Oxidative stress biomarkers responses to physical overtraining: implications for diagnosis., Free Radic Biol Med 2007; 43(6):901-910.

Markovic G, Misigoj-Durakovic M, Trninic S. Fitness profile of elite Croatian female taekwondo athletes. Coll Antropol 2005;29(1):93-99.

Matsushigue KA, Hartmann K, Franchini E. Taekwondo: physiological responses and match analysis. J Strength Cond Res 2009;23:1112-1117.

Mudd LM, Fornetti W, Pivarnik JM. Bone mineral density in collegiate female athlete: comparisons among sports. J Athl Train 2007;42(3):403408.

Pitts S, Blood E, Divasta A, Gordon CM. Percentage body fat by dual-energy $\mathrm{X}$-ray absorptiometry is associated with menstrual recovery in adolescents with anorexia nervosa. J Adolesc Health 2014;54(6):739741.

Purvis D, Gonsalves S, Deuster PA. Physiological and psychological fatigue in extreme conditions: overtraining and elite athletes. PM R 2010; 2(5) $442-450$.

Ratamess NA, Hoffman JR, Kraemer WJ, Ross RE, Tranchina CP, Rashti SL, Kelly NA, Vingren JL, Kang J, Faigenbaum AD. Effects of a competitive wrestling season on body composition, endocrine markers, and anaerobic exercise performance in NCAA collegiate wrestlers. Eur J Appl Physiol 2012;113(5):1157-1168.

Santos VG, Franchini E, Lima-Silva AE. Relationship between attack and skipping in Taekwondo contests. J Strength Cond Res 2011;25:17431751.

Sedeaud A, Marc A, Schipman J, Tafflet M, Hager JP, Toussaint JF. How they won Rugby World Cup through height, mass and collective experience. Br J Sports Med 2012;46:580-584.

Stanforth PR, Crim BN, Stanforth D, Stults-Kolehmainen MA. Body composition changes among female NCAA division 1 athletes across the competitive season and over a multiyear time frame. J Strength Cond Res 2014; 28(2):300-307.

Tornello F, Capranica L, Chiodo S, Minganti C, Tessitore A. Time-motion analysis of youth Olympic Taekwondo combats. J Strength Cond Res 2013;27:223-228.

Weber CL, Chia M, Inbar O. Gender differences in anaerobic power of the arms and legs-a scaling issue. Med Sci Sports Exerc 2006;38(1):129-137.

Zemski AJ, Slater GJ, Broad EM. Body composition characteristics of elite Australian rugby union athletes according to playing position and ethnicity. J Sports Sci 2015;2:1-9. 